\title{
Canada's Cold War in Fur
}

Joan Sangster-Trent University

Intense battles within the trade union movement over ideology and strategy are an integral part of Canadian working-class history throughout the nineteenth and twentieth centuries. Those debates were often intertwined with the history of the left, a fractious category that included divergent groups of revolutionaries and reformists, social democrats, and communists, who might disagree vehemently with each other, while embracing a similar conviction that leftists should be involved in the labour movement. Undoubtedly, the most dramatic instance of intra-left struggle within the trade union movement occurred during the Cold War, as social democrats and their allies led a largely successful campaign to remove known and suspected communists - and the unions they led - from trade union centrals like the Trades and Labour Congress (TLC) and the Canadian Congress of Labour (CCL). The intense Cold War battles fought roughly between 1946 and 1956, however, had deep roots in the interwar period, and they also had repercussions for labour long after 'communist' unions had been expelled form the TLC and CCL.

This article explores one as yet undocumented Cold War battle fought within the Canadian International Fur and Leather Workers Union (IFLWU), with a particular focus on the Toronto labour scene. Canada's Cold War in fur was shaped by international union politics, fierce ideological differences, state policies on both sides of the $49^{\text {th }}$ parallel, and the ethnic contours of the workforce. While the general parameters of the Cold War battle within the fur industry were similar across the country, Toronto was distinct: dual unions existed in the city from the late 1930s to the 1950s, the Toronto divisions were particularly sharp and violent, and the anti-communist Toronto union played a significant role in the Cold War merger of fur workers into the Amalgamated Meat Cutters and Butcher Workman Union (AMC) in $1955 .{ }^{1}$

How Cold War politics unfolded in fur had much in common with other anti-communist union battles: these were largely leadership rather than rank and file battles, and ideological differences were not honestly debated but instead became caricatured hyperboles. At the same time, the fur conflict was distinct because of its nationalist angle and its ensuing consequences. Unlike the electrical workers, there were not two rival unions created in Canada, and unlike the International Union of Mine Mill and Smelter Workers, fur workers did not man- 
age to sustain an autonomous national presence in Canada. Nonetheless, the IFLWU battle encapsulated the tragic irony of the Cold War in labour quite well. Continually invoking democracy as their guide, anti-communist trade unionists knowingly abandoned democratic and just practices in order to achieve their political goals, though in the final analysis, communists too abandoned democratic union decisions for Communist Party priorities. Moreover, by targeting not only communists, but also those who refused to shun them, trade union leaders created a broader Cold War 'chill' within the labour movement, encouraging an atmosphere of conformity, unquestioning acceptance of Canadian foreign policy, and a suspicion of oppositional militancy from the rank and file.

\section{Cold War Labour History}

The Cold War within the labour movement was primarily a long-standing contest between communists, including members of the Communist Party of Canada (CPC, and known after 1943 as the Labour Progressive Party, or LPP), and social democrats and liberal reformers, given strong leadership by the CCF-affiliated unionists. These divisions were obviously intertwined with broader international and North American Cold War politics. While Canada may not have witnessed the same public outings, imprisonments, and use of the electric chair as in the United States (US), Canadian communists were certainly persecuted, though often away from public view. As Reginald Whitaker and Gary Marcuse's research shows, anticommunist purges permeated everything from the National Film Board to the civil service, peace, educational and reform organizations, and of course unions. ${ }^{2}$ The Cold War also shaped immigration policy, and thus the emerging workforce; potential immigrants with suspected communist tendencies were denied entry, yet in the aftermath of World War II, the state turned a blind eye to former fascists. ${ }^{3}$ The most critical Cold War opponents contend that the state manufactured scares, ignored civil rights, and used anti-communism as a means of crushing anti-capitalist and anti-NATO dissent. ${ }^{4}$ Finding a middle ground, Reginald Whitaker and Steve Hewitt conclude that there was indeed some security risk from the USSR, but that Canada's 'insecurity' state purposely exaggerated this as a means of silencing dissent, and in the process, rode roughshod over the lives of those targeted. ${ }^{5}$

Trade unions were central to the Cold War, and indeed, the Cold War was one element of the post-war Fordist accord between capital and the mainstream labour movement. ${ }^{6}$ Since communists and social democrats both saw influence within the house of labour as a sine qua non of their political success, unions became the site of intense internal political struggles. Scholars exploring the Cold War in Canadian working-class history initially focussed on internal trade union politics, and later widened their purview to other organizations, such as women's trade union auxiliaries, consumer groups, and the peace movement. Very few Canadian authors examining the impact of the Cold War on labour suggest that 
the purges were a "necessity"; more often, they contend that the long-term consequences were negative for the entire labour movement. Irving Abella's 1973 study of the CCL remains an insightful analysis of labour's Cold War. While he reproaches social democrats for their abandonment of "truth and justice" in their relentless campaign against communist unionists, he is also critical of Communist Party policies. ${ }^{8}$ New Left historians have also attempted to rewrite communist labour history in North America without the blinkers of Cold War ideology, often by focusing on local, single-issue, and rank and file organizing, ${ }^{9}$ seemingly less tainted by Comintern directives. While their sympathetic analyses of a wide range of communist organizing has contributed important new perspectives, there is a tendency, as Bryan Palmer points out in a recent review of the historiography, to simultaneously sidestep unpleasant questions about decisions coming from the 'centre,' Party leadership, and Stalinism. ${ }^{10}$

Most historians are in agreement that the Cold War in labour had repercussions far beyond the few unions deemed 'communist.' In the TLC, according to Whitaker and Marcuse, anti-communism was used to help the AFL successfully suppress nationalist claims for autonomous Canadian decision making, purging unionists who would "not toe the internationalist line."11 Furthermore, independent socialist, even civil libertarian positions, became very difficult to sustain in this highly polarized atmosphere since all trade unionists who refused to join the anticommunist crusade were deemed equally suspect. When communists and their "sympathizers" were barred as delegates from TLC meetings, for example, those who expressed concern about this undemocratic practice were simply dismissed as naive-or worse, supporters_of revolutionaries who were "evil destroyers of democracy and freedom" and "saboteurs" to boot. ${ }^{12}$ The CCL campaign was similarly hyperbolic: their newspaper continually propagandized against communists, deemed to be "anti-Christian, godless, materialistic, disloyal, and a menace to democracy."'13 Even though social democratic leaders were the predominant victors in these battles, McCarthyism could in turn be used against them by antisocialist crusaders. ${ }^{14}$ In the final analysis, conclude Reginald Whitaker and Steve Hewitt, the CCF did much to support the Cold War, but "the Cold War did nothing for the CCF" ${ }^{15}$ as it suffered the fallout from anti-socialist campaigns waged in the name of anti-communism.

The state was not a neutral bystander in labour's Cold War. While some appointed bodies like labour relations boards had to appear neutral, the state was sympathetic to anti-communist unionists; it offered ideological support, and in specific cases such as the Canadian Seaman's Union or Maurice Duplessis' Quebec government, it intervened to facilitate the removal of communists from the union movement. ${ }^{16}$ Imagined enemies of the state were not only trade unionists and leftists, but in the civil service they might also be homosexuals supposedly more likely to succumb to the insidious blackmail of foreign agents circulating in Ottawa. As Elaine Tyler May and John D'Emilio argued some time ago, the interconnec- 
tions between the Cold War and gender, particularly the exaltation of heterosexuality and the heteronormative family, are quite significant. ${ }^{17}$ The question of gender is particularly important in union histories since some US feminist historians contend that we have exaggerated the conservatism of the Cold War period in women's labour history, when in fact the post-World War II era saw an increase in union equity campaigns on women's behalf. ${ }^{18}$ Lisa Kannenberg, in contrast, still maintains that the Cold War suppressed the unionization of women workers and stifled discussion of equality issues within the larger movement. ${ }^{19}$

The Canadian Cold War in labour was distinct from that of the US: we did not contend with the same 'race' questions that enveloped organizing in the US South; a few communist-led unions survived here without the terror of a TaftHartley law; and, at least in the case of the fur workers, the communist issue in Canada was linked to nationalist debates about Canadian union autonomy from US union leadership. Nevertheless, we cannot extricate our history from that of the US, since anti-communist battles were played out within the intricate politics of international unions that were essentially under American leadership control. This was precisely the case for fur workers whose union, the International Fur and Leather Workers Union ${ }^{20}$ came to its end during the Cold War.

\section{Interwar battles in fur}

Just as the insecurity state was rooted in a pre-Cold War past, so too was the interunion and intra-union conflict that characterized the Cold War struggles in fur unions. Long before the iron curtain fell, antagonistic divisions existed in the trade union movement that reflected different conservative, liberal, social democratic and communist perspectives. To understand the vehemence of the Cold War in fur, it is necessary to look briefly at the nature of the industry and fur union politics during the interwar years.

Fur production was characterized by a high number of small workplaces: in 1949, for example, there were 642 manufacturers in the country, concentrated mainly in Winnipeg, Toronto, and Montréal, and with a workforce that included a large number of Eastern European Jewish immigrants. Some local meetings and papers were in Yiddish, and the few remaining membership lists for Winnipeg indicate the geographical and social clustering of what was likely a strong Jewish union membership. ${ }^{21}$ This ethnic pattern was somewhat different in Montréal, where French Canadians also worked in the shops, and in Toronto, where nonJewish and Jewish workers actually had different locals at one point, causing some tension, particularly since the Jewish workers saw their non-Jewish comrades as more conservative. ${ }^{22}$

The work process within the industry was segregated more by gender than ethnicity: the skills required to create coats from pelts were primarily the preserve of men, apprenticed to learn the techniques of sorting, wetting and stretch- 
ing, blocking, and then cutting the skins. Skilled male fur workers, remembers one former worker of the interwar period, were the "aristocrats" of the garment trade; Jewish parents were pleased when a young woman chose a "young man in fur" as her economic future seemed secure. ${ }^{23}$ In contrast, women worked as sewing machine operators, made linings, and did the finishing of the coat. As a minority of the fur workforce, their jobs were designated less skilled and were remunerated poorly, even when they shared the same operator work as men. In Canada, their share of these positions also decreased in the post-World War II period, in part due to the influx of many displaced male fur workers from Europe. ${ }^{24}$

From the 1920s to World War II, the significant numbers of politicized, left-wing Jewish immigrants working in fur provided a cadre of union activists, and despite the gendered division of labour, women shared similar concerns with male workers about the low wages, contracting out, seasonally long hours, and unhealthy working conditions (respiratory problems were prevalent) in the industry. Ontario's Minimum Wage Board records indicate that female sewing machine operators often received "shockingly low" wages until employers, prodded by unions, were forced to comply with the law. ${ }^{25}$ In many respects, the organization of the fur industry was not unlike the garment trade, and there was some fluidity in their mutual leadership, as organizers like Muni Taub moved from positions in the International Ladies Garment Workers Union (ILGWU) to the Fur Workers Union. ${ }^{26}$

The fur industry posed substantial difficulties for union organizing, not only because of the prevalence of sub-contracting, the profusion of small workplaces, and the ease with which new businesses were set up, but also because many anti-union employers were ready to use injunctions, yellow dog contracts, dismissals of activists, and strikebreakers to maintain control of their factories. ${ }^{27}$ Although these employers might also be Eastern European Jews, their cultural affinity with their workers did not negate their inevitably divergent economic interests, and their fierce attempts to prevent unionization. ${ }^{28}$ In Winnipeg, to note only one example, the union was brought to its knees in the late 1930s after a year-long and difficult strike that involved hundreds of arrests when the notoriously antiunion Hurtig Furs successfully sued the union for over two thousand dollars in damages. ${ }^{29}$ Two of the most prominent Communist women organizing in fur, Pearl Wedro and Freda Coodin, emerged from Winnipeg battles in the 1930s only to find themselves respectively blacklisted and jailed after the strike's end. ${ }^{30}$

From the 1920s on, Canadian organizing was also characterized by political struggles between social democratic (or anti-communist) and communist fur workers. Nowhere were these conflicts more acute than in Toronto. The original Toronto Fur Workers Union was chartered by the AFL/TLC in 1913 and after a strike in 1923, increased its presence in the industry. By 1926, after a significant strike in the US in which communists faced down a gangster element, Ben Gold and other communist leaders took control of the fur workers until they were 
removed by social democrats, with AFL aid, in the late 1920s. Given this social democratic coup, the Communist Party's Third Period's call for dual unions resonated well with American communist fur workers, though in Canada, inter-union battles persisted throughout the early 1930s. Nonetheless, the struggle for control of fur unions was always a cross-border affair, with American leadership contests and union battles inevitably shaping the Canadian scene.

The consequences of these schisms, and dual unions in general, are a matter of historical contention. ${ }^{31}$ These political battles did focus union energies on acrimonious competitions for leadership control and they sometimes resulted in attempts to decertify other locals rather than organize new ones-a situation that only aided employers. The fights between competing Jewish factions, argues Ruth Frager, may have also alienated other 'non-aligned,' non-Jewish workers. ${ }^{32}$ Fratricide in fur, however, was not only a consequence of the Communist Third Period of the early 1930s, as dual unions emerged in Toronto during the Popular Front of the late 1930s. Initiatives from the International office in New York, and the new Communist line of 'uniting to fight fascism' helped to push the two sides together under one union roof, and from 1935 to 1937, a brief period of harmony prevailed. The Toronto peace pact soon fell apart, and a breakaway fur workers union, led by social democrat Max Federman, was chartered directly under the AFL in 1938 (a relative rarity), with the blessing of AFL president, William Green. ${ }^{33}$

No one was more important to the long history of the Cold War in fur than Max Federman. A Jewish Polish immigrant who immigrated to Canada at nineteen, Federman found work in the fur industry in 1920, and by the end of the decade, he had moved into the leadership of the social democratic fur faction in Toronto. His right-hand supporter was Harry Simon, a Ukrainian Jewish immigrant who arrived in Canada in 1921; by age nineteen, in 1928, he had been elected business agent of his fur local. Both were committed social democratic unionists; both were supporters of Poale Zion, or Labour Zionism, a group that advocated the "mobilization of the proletariat to a Zionist revival" intended to secure a homeland for Jews in Israel. ${ }^{34}$

By the late 1930s, therefore, an AFL (social democratic) and CIO (communist) union in Toronto competed for members, territory, and over union property $^{35}$ : the contest was intense, violent, and unrelenting. Though bitter personal hatreds emerged, we should not reduce the Cold War only to sectarian struggles and petty politics. Social democrats and communists did have different views on foreign policy, divergent understandings of socialism, and varied cultural-ethnic identities. Indeed, the case of fur reminds us to be wary of homogenizing any one ethnic group for divisions were intense within a cadre of Jewish unionists. While Federman saw religious practice, Jewish culture, and Zionist support for a Jewish homeland as interconnected, elements of identity, his Jewish communist opponents' sense of ethnicity was based on a cultural, though definitely secular identi- 
ty. They portrayed themselves as more 'internationalist' in orientation, interested in class solidarity rather than a Jewish national state. During the early 1930s, for instance, communists opposed Zionism, labelling it a fascist and capitalist enterprise and thus creating even more political animosity between the two left camps in fur. While communist opposition to the creation of a Jewish state was moderated after World War II, a lingering antipathy to Zionist organizations remained. ${ }^{36}$

During the thirties, remembered Al Hershokovitz, a communist fur organizer who subsequently left the Party in the late 1940s (becoming Federman's assistant), there were "hot battles in the streets" for control of union territory. ${ }^{37}$ Mirroring earlier patterns in the American fur industry, these struggles sometimes involved paid protectors or hired gangsters. In one confrontation, Federman's supporters attacked the communists, taking baseball bats to a car and chasing opponents down Spadina Avenue. In the trial that followed in a Toronto court, it was ascertained that the "strong arm men" hired by Federman had criminal records, were not fur workers, and were promised cash in return for their services. ${ }^{38}$ Federman's AFL union countered with its own accusations, claiming "Communist hoodlums" attacked a union meeting at a member's house, "brutally" assaulting his wife. Both sides routinely charged the other with employing violent tactics, intimidating workers, collaborating with the bosses, and ignoring contracting out when it suited them. Given the incomplete historical records, it is difficult to assign blame to only one side, though it seems that only the social democrats were taken to court. One thing is certain: these battles took on a masculine air of bravado and bullying. While activist female fur workers were not shy about blocking workplace doors and physically intimidating scabs during strikes, they were usually absent from all-out union rumbles, and the prevalence of this violence undoubtedly played a role in marginalizing them from the leadership of the union.

As in the later Cold War, these struggles were waged most decisively at the upper levels by leaders who often chose to disregard workers' interests. The brief attempt at unity fell apart because Max Federman and Harry Simon were charged by the US head office with fraud. While their self-appointed union committee cleared them, the international ILFWU (admittedly including their opponents) found them guilty and fired them. Federman claimed the charges were nothing but political retribution, ${ }^{39}$ and then managed to secure his own directlychartered AFL local, creating dual unions in the city. Left to sort out the mess in fur, The Toronto District Labour Council (TDLC), with the aid of labour lawyer J.L. Cohen, investigated and concluded that the creation of fake worker entries had been made in the unemployment benefit account book, creating a secret fund then used by the Federman group, with the checks cashed by a local poolroom proprietor who testified that he got a few cents and promise of a job in the fur shops for one of his relatives. ${ }^{40}$ Federman admitted to some parts of the scheme but argued that the funds were used for organizing work in Montreal. Simon and 
Federman cried "bogus trial," ${ }^{41}$ but the Labour Council decided there was ample evidence of guilt; even $\mathrm{Al}$ Hershokovitz, later Federman's right hand man, claimed in retrospect that he had been playing "hanky panky" with the books. ${ }^{42}$

The declaration of war in 1939 shifted the political terrain dramatically, as the Communist Party's defense of the Hitler-Stalin pact now put them on the moral defensive. So too did the internment of communist union organizers like the ILFWU's Muni Taub. In a trade so heavily populated by Jews, excusing the Hitler-Stalin pact was a political liability to say the least, though some committed Stalinists like Taub defended it, even years later. ${ }^{43}$ The AFL union used the Communists' about face to full advantage, often appealing to both employers and workers on the basis of Jewish fears of antisemitism. ${ }^{44}$ The communist union, they claimed, had abandoned the fight against the Nazis; voting for Joe Salsberg, said one of their pamphlets, endorsed by the Canadian Jewish Congress, was like voting for Hitler or Goebbels. ${ }^{45}$ Most anti-communist propaganda never mentioned gender, appealing to workers primarily on the basis of their loyalty as Canadian citizens, or as Jews fighting anti-Semitism, but it is revealing that Pearl Wedro was pilloried in terms that also mocked her appearance. Whoever appointed this "Stalinist fish wife" to a leadership position, asked the AFL union contemptuously, perhaps another small indication of the masculinist mindset that was deeply ingrained in the union. ${ }^{46}$ The AFL union also threatened fur employers, telling them not to sign any agreements with the CIO union as its leadership was simply a "fifth column" of Stalinist agents supporting Nazism. ${ }^{47}$ Should they disobey, they would be exposed publicly as 'traitors.' When the USSR joined the war, these attacks declined but the political antagonisms in fur simply festered for the remaining war years.

\section{The Cold War}

For a fleeting moment, the IFLWU might have felt optimistic at the war's end. Fur workers used the wartime labour situation to organize more locals and obtain better contracts, and with the aid of their union counsel, J.L. Cohen, the IFLWU utilized the regulatory powers of the War Labour Board to consolidate union gains. Workers now enjoyed a 44 hour week, a week's vacation, a closed union shop, and contract clauses on the fair distribution of work. In Toronto and Winnipeg, women's union auxiliaries were founded; a short-lived publication of the CIO union, The Beaver, was initiated; and there were new efforts to organize tanneries. American IFLWU president, Ben Gold, who was given to lecturing Canadian unionists from time to time, urged the Toronto IFLWU organizer, communist Fred Collins, to expand on these gains and beef up the union's grass roots organization by bringing in "the leather workers, holding educationals, classes, lectures and concerts." In Gold's view, things could only improve in Toronto as the past leadership had proven either "incompetent or dishonest."48 
However, as the Cold War heated up, cooking the books seemed a lesser evil in comparison to the Soviet Union in the eyes of both the CCL and the American AFL leadership, who identified Max Federman as their key ally against communist trade unionism. The Canadian IFLWU was expelled from the CCL in 1950 on the pretext that they had criticized the CCL leadership on the issue of wage and price controls, ${ }^{49}$ but essentially because of its communist leadership. The general process of excising communists from the labour movement was similar across many unions. Propaganda in the union press often laid the groundwork for expulsions, and it was generally the leadership, rather than the rank and file, who initiated these expulsions, sometimes disguising their true ideological motives with other justifications. These were also complex cross-border affairs, characterized occasionally by antagonistic US-Canada union relations, but more predominantly by cooperation between anti-communist labour leaders. The nature of the industry and union did have some bearing on the process: unlike influential mass production unions like the UAW, where both communist and social democratic/liberal factions had considerable power, the ILFWU had no internal anti-communist opposition to nurture into the leadership, so expulsion was the quick and preferred option.

At precisely the moment the IFLWU was expelled, it had to cope with an industry in economic trouble as fur sales were in a slump after 1949. The ILFWU struggled on independently, though it also faced raiding attempts by the AFL fur union, hoping to expand into Winnipeg and Montreal-appealing to younger Montreal workers, claimed one IFLWU official with disgust, with a combination of anti-communism and "booze parties." The AFL fur union tried to entice workers away from the IFLWU by stressing two issues: it claimed to be far superior at bargaining, (though there is not the evidence to support this), and it relentlessly pressed home a patriotic appeal: "we know that you are loyal Canadians and that you believe in the Canadian way of life. We don't blame you for the swindles, sellouts....the espionage work for the Soviet Union." ${ }^{51}$ Meanwhile, in the US, court cases launched against the international president, Ben Gold, an open Party member, were severely crippling the IFLWU. When Gold resigned, the new leadership considered a new home, though ironically, it was a change in Communist policy in the early 1950s, namely a new directive that union members try to find refuge in the "mainstream" 52 of the labour movement, that also pushed the fur workers into a merger with the AMC. The result was the largest Cold War battle in the union yet.

The Canadian IFLWU District 10 was automatically expected to participate in the merger, even though the absence of a Taft-Hartley law here made their situation different. Ben Gold recognized this when he gently chided Canadians for not being brave enough in the face of McCarthyism: "we have been under fire all along...you have had it easier." ${ }^{3}$ Yet in Montreal, the Canadian union faced similar state persecution. In 1954, Maurice Duplessis introduced legislation that essentially mimicked Taft-Hartley, decreeing that unions with communist officers would 
be denied standing with the Labour Board-putting all IFLWU contracts in jeopardy. ${ }^{54}$ The IFLWU President, Robert Haddow, a Communist, and machinist by trade, feared this would mean the union's "destruction," 55 in Quebec, and the Montreal IFLWU did become legally independent from the International as a defensive measure. ${ }^{56}$

Still, Communist Party advice to abandon independent unions like the IFLWU was geared more towards the American situation, as the fear of intensified legal persecution, along with the impending AFL-CIO merger, shaped the decision to find a safe haven in the AFL-CIO. It did not really matter that the Canadian labour situation was somewhat different: the Canadian Party was of little concern to Soviet and Cominform ${ }^{57}$ advisors, the Canadian IFLWU was a mere 3500 members, and it was simply assumed that key trade union decisions were made at head offices in the US.

Since the AMC had recently been granted the jurisdictional rights to leather workers by the AFL, and was already raiding some IFLWU locals, a merger was seen as one way to preserve fur and leather worker locals. Confidential discussions began in the fall of 1954, before Ben Gold was completely ousted, led by the long-time ILFWU Vice-President, Abe Feinglass, who had left the Communist Party six years previously. A merger agreement was hammered out and presented in December 1954 to the AFL Executive Council, and in January to Canadian and American IFLWU representatives meeting in special convention. The convention document was purposely sugar coated: the merger was justified by the Fur Workers' long-standing political commitment to "labor unity" and rationalized with claims that the autonomy, assets, and rights of locals would be respected. Union leaders told the delegates that signing anti-Communist affidavits and banning Ben Gold forever was a "weakness" in the pact to be sure, but not too great a price to pay for unity. ${ }^{58}$

Selling the merger to fur workers was not initially difficult for Feinglass, and AMC leaders Patrick Gorman and Earl Jimerson were also solidly behind the deal - and why not, with the prospect of 70, 000 new members, and substantial assets, including a 1.3 million resort property in upstate New York? ${ }^{59}$ Getting the AFL's necessary approval, however, proved to be an uphill battle. The AMC presented the merger to the AFL as a "new and dynamic" strategy for combating communism: rather than expelling whole unions, leaving all these workers at the ideological mercy of their leaders, this merger would "amputate the tentacles of the Communist octopus" by integrating workers into the AMC where their loyalties would be "remolded." ${ }^{\circ}$ Over the next six months, as AMC leaders appealed repeatedly to the AFL Executive Council to secure their approval, a pattern became clear: every time AFL President George Meany objected to the merger, claiming there were still communists in the IFLWU who were just looking for a devious way to hide in the AFL, the AMC revised the merger plans to provide more authoritarian, drastic guarantees of "de-communization." They agreed that 
any "communist" activity by members could lead to expulsion of the local, that communists were to be barred from future election, that the new AMC Fur Department would be under the close grip of the AMC Executive, and that expulsions could take place even without a trial. In turn, Feinglass and the AMC leaders pressed downward on all the IFLWU locals, expelling suspected communists and even going to the ridiculous length of banning any participation in the New York City May Day parades!

There is some evidence that these AMC leaders did not expect such strong AFL directives and grew disheartened by the ferocious extent of this witch hunt. Feinglass was rather dismayed when members were expelled for attending May Day demonstrations, while Gorman privately complained to some other union heads about the "tommyrot" of AFL hypocrisy on de-communization, and about the "evil influence" of ILGWU President David Dubinsky who had "wanted fur for himself,' and who was behind the AFL objections. ${ }^{61}$ In public, however, they joined the incessant calls for the elimination of all communists from the labour movement, they provided information to HUAC, and they cooperated with Meany's special anti-communist envoy sent to keep an eye on them. ${ }^{62}$ Meany himself was under pressure from other AFL leaders who were skeptical that "surface changes" in the IFLWU would "eliminate" all the resident communists, whom they envisioned as "traitors to their fellow man, to their country, and to their God." ${ }^{33}$ The AFL's suspicions of the IFLWU were not surprising considering that communist newspapers on both sides of the border were actually in favour of the merger; in May of 1955, the Canadian Tribune extolled it as a "new era for labour." 4

When the merger was first announced in Canada, it was heartily endorsed by IFLWU District president Haddow. Max Federman, in contrast, headed for the AFL Executive Council meeting in Miami in February of 1955, to tell them that his AFL-chartered union resolutely opposed the merger as the IFLWU was controlled by communists, "a cancer" that he had battled for "35 years of his life"; he even claimed that Feinglass was still a communist in disguise. ${ }^{65}$ Accusations about Feinglass were treated with written guffaws by the AMC leaders: if he is a communist, they joked, he is the most "double crossing communist that ever existed" because, more than anyone else, he "de-communized" the union. ${ }^{66}$ Yet, a few months later, Federman headed south again to appear before the AFL in order to endorse the merger. Why did his tune suddenly change? He was promised a seat on the International Fur Department's Council, and was essentially reassured that he would have the upper hand in the union, backed up by AMC leaders. ${ }^{67}$ Canadian anti-communist trade unionists realized they could finally eliminate their long-time foes through this merger - and how sweet revenge must have seemed to Federman and Simon especially. Federman was now so keen on the merger that he wanted his locals to affiliate immediately, but was held back until the final merger was accomplished.

Before this change of heart, Harry Simon had also objected to the merg- 
er, and to make his point that the IFLWU was controlled by communists, he sent the AMC leadership (and then on to the AFL) a list of eleven unacceptable leaders and staff members in the union. This blacklist now became the unchanging template for Canadian purges. ${ }^{68}$ Canadian Labour Congress President Claude Jodoin also intervened with similar intentions. ${ }^{69}$ The secret list operated much like McCarthy's, including suspicious people as well as known Party members, and providing no real opportunity for people to defend themselves. Some on the list were open Party members, like Haddow, but others like Montreal business agent Charlotte Gauthier may have simply been unionists who agreed to work with communists. Unaware of the full extent of the blacklist, Canadian communist IFLWU leaders continued to support the merger through the spring of 1955 , faithfully following the Party line. Without a Taft-Hartley Act, they surmised Canadians might escape signing non-communist affidavits. As Haddow told American leaders, Canadian unionists "expect to be governed by their own laws....resentment would result from the stigma of being governed" from abroad. ${ }^{70}$ AMC and AFL leaders, however, had a different view of the border. While the Canadian unionists usually equated the international divide with autonomy, American leaders tended to see the Canadian District 10 as just another district to be brought into line.

When AMC leaders came to Canada in the spring to sell the merger to the IFLWU, the latter continued to plea for "Canadian autonomy" and the "right to differ" over important issues. Haddow's nationalist speech to the group criticized the overbearing and more reactionary American state and reiterated District 10's wish to sign on only if they could secure their "traditions....leadership and autonomy." American leaders warned that Taft-Hartley might be the price to pay for the merger, and that this was something any "loyal citizen obeying the law" should have no qualms about. Americans speeches about loving Canada likely scored few points, grating on the Canadians' nerves: "I like Canada," opined American leader Marvin Hook, "I like your country, although I have never yet had time to go fishing here.... We will put everything back that we take out. There is great potential here, a frontier of resources." Probably more reassuring was Feinglass' claim that the AMC did not intend to "dictate" to the Canadians; he also reminded them that dual, and duelling, unions were crippling Canadian organizing. AMC leaders were thus speaking two languages: a tough 'take it or leave it' rhetoric, and one which reassured by claiming that some vestiges of Canadian sovereignty might be salvaged. ${ }^{71}$ They had at least learned that the Canadian IFLWU was unlikely to appreciate the maladroit assurance they offered to Harry Simon that they would insist on the new union being "thoroughly American" with strong "allegiance to the US [state]." 72

As the deadline for AFL approval approached, two groups in particular got cold feet: New York City (NYC) and Canadian District 10. The AMC was desperate to bring them into line, and it may have been easier to do in Canada than NYC where a larger, powerful fur council—Ben Gold's power base-had histori- 
cally controlled elections. As pressure mounted on Gorman to get tougher with communists, he was able to use the Canadians as an example of his anti-communist credentials. In a series of letters to well-known anti-communist activist Father Charles Rice (who opposed the merger since he believed the evil communists would simply hide underground in the union), Gorman assuaged his concerns when he wrote, "this week we will kick out about five in Canada...and as fast as we find them, out they go." "73 In fact, Gorman sometimes claimed that Canadian leaders were eliminated before they had actually resigned $;{ }^{74}$ some Canadians staffers were dispirited to hear from New York newspapers that they had been let go a rather insulting way to receive a pink slip.

The Canadian District balked at the AMC's renewed demands for leadership resignations, feeling "it is clear that the Amalgamated is willing to pay the price [for the merger] as long as the sacrifices are made by Canadians." However, concessions were made: at a May meeting at the Royal York Hotel in Toronto, Haddow sat with four US union leaders and watched as they dictated his resignation. Toronto organizer and communist Dewer Ferguson, in the midst of a unionization campaign at a local tannery, followed suit. Haddow publicly urged the IFLWU to proceed with the merger though he was permitted to "record the view that our officers were wrong in succumbing to a McCarthyite witch hunt" led by the AFL and TLC. ${ }^{75}$ Although other Canadian IFLWU leaders feared that the union could not withstand a "life and death" struggle with the AFL, talk of a Canadian secession movement began to circulate. Meany was nonplussed when informed of the possibility: if this is the "sacrifice" we have to make for a successful merger in the US, he commented, we can always regain non-communist fur workers later. ${ }^{76}$

After Haddow resigned, the Canadians were still under the impression that they could salvage some autonomy, but they were wrong. At its May meeting, the AFL again rejected the merger, and using Simon's blacklist as their measure, demanded more purges, something Federman later celebrated as part of his contribution to union history. Canadian locals across the country now protested more assertively to the AMC; over the summer, their letters and telegrams of "burning resentment" flooded into the AMC Chicago office. Asserting that no more resignations would be accepted, they denounced the "beheading" of the Canadian district, and the violation of democratic rights: we need the right to "form our own policy in keeping with Canadian needs, to elect our own leaders, to differ when the national interest is involved," wrote the Vancouver local. ${ }^{77}$

To the AMC, these Canadian rumblings of discontent were irksome, but probably less worrisome than the US situation. In July, the AMC closed in: Feinglass came to Montreal, "took over the finances, stopped the subsidy, cut off funds, and put the remaining organization on the Intemational's payroll." Hershkovitz, now working for Federman, tried to intercede on behalf of some of his former comrades but admitted he could do nothing to stop further purges: 
Gorman, he reported, "regretted" the attacks but "Federman and Meany" would not rest until more leaders resigned. ${ }^{78}$ On 5 August, a few days before the next AFL Executive Council meeting, telegrams were sent to four more Canadians on the Harry Simon list, ordering them to resign. When they refused, their locals were put into receivership.

Six Canadian locals called an emergency convention on 20 August to consider seceding as an "autonomous" union. Fur workers and their leaders bitterly vented their anger: "We were prepared to make peace with Federman on honourable terms," they wrote,

\footnotetext{
"but he demanded the whole organization and Meany agreed.... "The merger was negotiated without our agreement, consent or consultation.....we got fine speeches about democracy but broken promises. Leadership was removed without our consent, the district was destroyed ... from day one we were treated like colonials to be dictated to." ${ }^{\text {80 }}$
}

Handing over the union to Federman, they charged, meant sweet deals with employers and future "intimidation from the US." Memory of the battles of the thirties also weighed on their minds: Haddow's hand written list of the pros and cons of unity with the AFL fur union had included the word "gangsterism" under the AFL-Federman column. ${ }^{81}$ Abe Feinglass appeared at the convention to nip the secession movement in the bud, but it was ultimately the Communists who did so. After the convention had vented its nationalist anger, voting for independence from the AMC, a committee of seven was set up to explore secession. Four of the IFLWU communist leaders on the committee capitulated, offering their resignations and accepting the merger terms. ${ }^{82}$

As Communist Party pressure was clearly involved, Federman was contemptuous of this latest flip flop. ${ }^{83}$ Because of the Party's endorsement of 'mainstreaming' as a union strategy, communist leaders in the IFLWU bowed to humiliating terms, the abandonment of free union elections, and a purge even Feinglass termed "ruthless." ${ }^{44}$ By the time the AFL Executive met in October, at least two more on the Canadian list had been forced out. Satisfied that the AMC had thoroughly eliminated communist leaders in the IFLWU, the AFL approved the merger, though it was reassured that even more communists would be pushed out of the union in the future.

Dismissed Communist organizers like Muni Taub and Pearl Wedro found themselves unemployed and blacklisted. The merger did allow the Montreal local to safely reintegrate with the International, which it did in 1956. It is questionable, though, how much was gained for fur workers. In the US, argues Bert Cochran, the IFLWU benefited little from the merger, and might as well have continued as an independent. ${ }^{85}$ In Canada, other communist-led unions which had been expelled from the CCL did resist mainstreaming: the UE (United Electrical 
Workers) with an independently-minded leadership refused to follow this advice, and the International Union of Mine Mill and Smelter Workers managed to survive as an independent Canadian entity for some time, despite raiding campaigns led by the United Steel Workers. ${ }^{86}$ It is difficult to say if the IFLWU, a much smaller union, would have survived as well, especially in the face of continuing raids and a declining industry. Certainly, once the IFLWU embraced mainstreaming as the only way forward, they were trapped in a merger that knew no end of leadership purges - though these were also related to the union's lack of power within the international, and the existence of the anti-communist, Toronto-based dual union, which not only provided US leaders with a blacklist, but kept urging them to implement it. It was a rather ignominious end for the IFLWU, a union with a proud tradition of skill, militancy, and political activism.

\section{Cold War Consequences}

Nor was the Cold War in fur entirely over. Well into the mid 1960s, the social democrats and communists sparred within the fur section of the Amalgamated, though Federman was successful in keeping communists out of the Canadian leadership. Leadership control by communists was simply replaced by leadership control by social democrats, aided by the AMC head office which directed who could and could not run for office in Canada. ${ }^{87}$ Wedro eventually found a factory job in Toronto, and once represented her local on the Toronto Fur Board. During elections, Federman and his leadership routinely put out leaflets denouncing "oppositionists" like Wedro in virulent anti-communist language, claiming they were also dangerous "splitters" who opposed the 1955 merger. Hershokovitz was occasionally targeted by anti-communists, but it was so clear that he had changed sides that these attacks came to nothing. Joe Salsberg also made a political comeback after 1956, speaking at fur worker educationals. After renouncing the Communist Party, he was no longer equated with Hitler by social democratic fur leaders.

The persistence of anti-communism was well illustrated by the case of Bill Mitchell, who was purged as a Montreal business agent in 1955, but in 1956, left the Party. He wanted to run for election as business agent in 1957 but the AMC said no. He had to pass a stringent repentance test that included securing Meany's blessing. It would take more than a routine 'apologia' letter to do this. Mitchell could not simply reject the Communist Party; he had to declare that he "regretted ever being a communist" and denounce all communist ideas, "everywhere." 98 Groveling in anti-communist mea culpas was the price to be paid, and Mitchell acquiesced. For communists who once devoted all their waking hours to these ideas, one wonders how they coped psychologically with being pressured to say their lives had been spent uselessly.

The continuing fear of communism was fanned after the merger by the Anti-Communist Fur Workers League, a small but vocal US-based group that lob- 
bied for more purges, claiming in their newspaper, The Anti-Communist Fur Workers Voice, that the union was not sufficiently "cleansed of the communist plague." "You can't get rid of an octopus by cutting off its arms," they wrote, but only by removing "the head." There were some indications that they had links to Max Federman. Both expressed continuing animosity towards Canadian fur organizer, Myer Kling, who moved to the US in the thirties to work for the IFLWU. Kling admitted to spending a few years in the Canadian Communist Party from 1929 to 1932, a confession that haunted him for decades. Referring to Kling as this "vermin, Stalinist hatchetman, alter boy of Ben Gold," the paper claimed he was the "chief prosecutor against Federman....used to take [communist] control in Canada [in 1938]." If Federman had provided this information, he had mixed up his prosecutors. The Anti-Communist Fur Workers League continued to provide blacklists to the AMC, and they lobbied to have Kling deported to the Soviet Union where they stated he should meet the same Gulag fate as Soviet subversives.

The AMC leadership placated these anti-communist lobbyists, but privately, they seemed to tire of the witch hunt. They did not fire Kling and paid for his long legal battle against deportation; at his victory celebration in 1962, Gorman even criticized the witch hunt waged against him. Central to Gorman's views on the Cold War was the concept of repentance, and it is interesting that the AMC's anti-communist pledges were accompanied by a required statement of which church one belonged to. If former communists were sufficiently penitent in word and deed, they should be welcomed back into unions. Reintegration also became synonymous with American patriotism. As Gorman had written to Father Rice about the fur workers: we should "pray for them, we may not be able to make them Christians, but we can make them Americans"- surely a reference to the Jewish heritage of many workers. ${ }^{90}$

By the 1970s, the ethnicity of fur workers in Canada altered as Greek and other European immigrants became the new work force in the fur industry. The legacy of the Cold War on the union, however, was still imprinted on the AMC, later merged into the United Food and Commercial Workers. Federman, who continued to lead the fur workers, argued at conventions during the 1950s and 1960 s that the peace movement was suspect, and that there should be no "appeasement" of the Soviet Union. He still supported an anti-communist loyalty oath in the 1970s so that "no member of the Communist Party will ever hold union office again." " He remained committed to Zionism, using the fur union to advertize his Labour Zionist views. ${ }^{92}$ Israel, he argued, was the "hope of democracy" in the Middle East, positioned against "reactionary Arab forces." The war in Viet Nam was also endorsed as a noble cause, a "crusade against communism." 94 Federman was not the only Cold Warrior in the labour movement; more broadly, some union leaders' fervent endorsement of Cold War ideology helped to stifle critiques of American foreign policy, from the Marshall Plan through to the Viet Nam War, and it also acted as a more general 'chill' within the movement on any 
left-wing dissent that, in their minds, bore a resemblance to communism.

\section{Gender and Ethnicity in Cold War Battles}

During this long Cold War in fur, the rival Canadian fur unions were united only once, in their joint effort in 1947 to rescue five hundred Europeans from displaced persons camps after the horror of the Holocaust. This effort purposely sought single male workers, and neither fur union fundamentally challenged the gendered division of labour and differential wages within the industry. Nor was there concern expressed in the 1950s as women disproportionately lost their jobs as the fur industry faltered. Although it may appear that the Cold War had the same consequences for male and female workers, a closer examination of new organizing and equity issues suggests that gender needs to be taken into account.

New organizing did not fall completely by the wayside after the ILFWU was expelled from the CCL; the union held their own, even as pariahs in the official union movement. ${ }^{95}$ Had it survived, the IFLWU had the potential to reach out to new immigrants, women, and non-Anglo/non-white workers as it was trying to extend its base in fur to new locals in tanneries, shoe making, and leather goods, small workplaces where women were a significant part of the labour force. In Vancouver, Pearl Wedro organized a string of shoe makers so small in size that she astutely secured a common agreement to protect all of them. ${ }^{96}$ In another leather goods workplace in southern Ontario, Wedro also tried to raise the issue of equal pay for women workers during the organizing effort. ${ }^{97}$ After the merger, there is little indication of continuing organizational fervour for such marginalized workers. Indeed, the AMC, which admitted it was literally 'made' with amalgamations, was now most interested in merging with the large United Packing House Workers of America. Nor can we discount the fact that fending off Cold War attacks took up inordinate union time and energy that might have been spent on new union organizing. ${ }^{98}$

There was also renewed discussion after war's end within the IFLWU of separate women's committees, designed to train female union leaders and address issues of equal pay, maternity leave, retention of seniority rights on maternity leave, and special health protections for women's work. ${ }^{99}$ Women's committees (for workers) and women's auxiliaries (for wives of workers) were originally to be organized jointly, but by 1950, it was suggested they work separately, sharing some projects such as International Women's Day. ${ }^{100}$ Canadian organizers Pearl Wedro and Charlotte Gauthier were involved in the organization of the international women's committee, with Gauthier serving as secretary. ${ }^{101}$ In Canada, with a smaller membership base, the union had more success setting up auxiliaries, designed, as one stated, "to help our men fight for better working conditions and better lives for our families." ${ }^{102}$ Some were involved in respectable local philanthropy, ${ }^{103}$ but others addressed political issues, such as women workers' right to collect UIC on the same basis as men, and the need for day nurseries. ${ }^{104}$ 
The IFLWU's efforts to address the specific needs of women workers may have been, in part, an attempt to secure the loyalty of a minority constituency in the union in difficult, anti-communist times, though the union agenda also mirrored a long-standing Communist political platform on women's equality. One should not overemphasize a heartfelt commitment to women's equality in a union that had been built on masculinist power structures. On hearing a resolution for more action on equality issues from the women's committee in 1946, Gold paternalistically acknowledged this little "spanking," from the women, and he asked that they add words of praise for the union's good track record on women's wages and status. $^{105}$ Gender equality may have been more 'convention talk' than action, but the AMC was even less interested in women's issues. There were no women organizers in the new AMC in Canada, though Gauthier, originally on the black list, was later re-hired as the business agent in Quebec, perhaps because of her language skills and disavowal of her earlier communist contacts. The union's 1962 celebration of its history featured pictures of its all-male executive board. Nor were the specific needs of women workers, or issues like equal pay, discussed in the Fur Department section of the AMC paper, The Butcher Workman. Admittedly, assessing the impact of the Cold War on women fur workers inevitably involves conjecture about a series of 'mights.' However, it is clear that women were transferred to a union without the same tradition of concern about the woman question, with a leadership in Canada that disdained democratic process in favour of political control_ and the latter has proven to be key to women's ability to have gender equity issues raised in unions.

\section{Conclusion}

Cold War battles within the North American labour movement were shaped both by common, broad influences, but also by historical, regional, and political specificities. Canada's Cold War in fur was influenced by the ethnic complexion of the workplace, by the Canadian IFLWU's place within the international union, by state policies (especially the US Taft-Hartley Act), and by the contending political visions of social democratic and communist politicians. These political contentions were grounded in a long history of conflict, ideological debates, and contests for power earlier in the early twentieth century, and they had an impact after McCarthyism had abated.

During the Cold War, TLC and CCL unionists became uncritical collaborators with both capital and the state in an anti-communist crusade that claimed to protect democracy for workers, while using undemocratic and authoritarian methods to do so. They beat the drums of xenophobia, dividing fellow workers into patriots or traitors, us and them, good and evil. Even if some unionists, like those in the AMC, were privately dismayed by the ferociousness and irrationality of the Cold War, they joined in the public denunciations and mouthed the same 
rhetoric. This is not, however, to idealize Communist-led unions, which could also play fast and loose with democracy, reflecting the earlier Stalinization of communism.

The Canadian IFLWU managed to remain viable after its expulsion from the CCL, only to be pushed reluctantly into a merger five years later, in large part due to Communist party pressure. This is a cogent reminder that attention to international and national leadership, and Party decisions from the 'centre' can not be excised from our assessments of communist labour organizing. Party politics, $\mathrm{Al}$ Hershkovitz recalled when explaining his exit from the Party, too often trumped trade union organizing: "it was more important [for the Party] to get 5 Tribune subscribers than 5 cents more for the workers." ${ }^{106}$ The Cold War in fur was distinct from other Cold War union contests because of the extent to which the merger became wrapped up in questions of Canadian nationalism and autonomy within the international-read American-labour movement. In the original expulsions from the TLC, argue Whitaker and Marcuse, anti-communism was used to curb Canadian attempts to assert some political autonomy. In the case of the IFLWU, autonomy was clearly sacrificed to the overall anti-communist goals of the international union. ${ }^{107}$ Still, however compelling the IFLWU's aspirations for autonomy from Taft-Hartley were, the way in which nationalism was used in this struggle underscores its many faces: it was not, in itself, a positive force for it could be used by radicals, democrats, anti-communists, or in this case, rather cynically by the Communist Party. ${ }^{108}$

National autonomy may have been the most visible issue at the time, but in retrospect, the merger also had consequences for women in the IFLWU. The merger of the IFLWU, with some concern for women's equality, into the larger AMC, with almost no interest at all in these issues, meant that an opportunity to address gender equality in the trade union movement was lost. The ethnic contours of the IFLWU inter-union and intra-union conflict were more complex, and somewhat distinct, since the Cold War in fur was fought out between two competing 'cultural-political' factions within one ethnic group. The struggle for union ascendancy between Jewish social democrats and communists is generally interpreted by historians as a destructive contest, dividing workers from each other and inhibiting trade union organizing. While dual unions certainly had negative effects, we should not dismiss this contest as only narrow sectarianism. For both social democratic and communists during the long Cold War in fur, winning over members to new political ideas was perceived to be a potent means of moving the process of social transformation forward. Both sides held passionately to their beliefs, linking them to different visions of socialism. Both sides represented competing notions of Jewish cultural identity: one secular, stressing class and internationalism, believing in the success of the multicultural Soviet project, and one more religious and Zionist, calling for a Jewish state, and deeply suspicious of the Soviet project. Politics shaped the Communists' union agenda, but also 
Federman's, including his Labour Zionism, and the emphasis he placed on practical bargaining and respectable unionism rather than revolution. Given the current union movement's contentious debates about Israel and Palestine, we should probably be sensitive to the importance of foreign policy issues to these earlier trade unionists, and also to their commitment to political issues, at home and abroad, that went beyond bread and butter unionism.

In the aftermath of the merger, the social democratic victors wrote the history of the union. Every historical speech, newspaper article, and anniversary program Max Federman created either omitted all communist leaders or grouped them under blanket denunciations of their nefarious actions. Any chance to recount the union history was another opportunity to celebrate the victory of anticommunists over communist "conspirators" who tried to ruin and "destroy" the union. ${ }^{109}$ In Federman's historical writing, events also hinged on his important interventions ${ }^{110}$ in the Cold War, so much so that in the 1960 s, when he offered to create a public history for the international, Feinglass and Gorman, rather irritated, rejected his offer. ${ }^{111}$

Communists on the losing side created their own personal histories in which they remained loyal to their communist pasts without really questioning the Party. Pearl Wedro and Muni Taub struggled later to rationalize the Party's decision of 1955, finding some good in it, even though they were both upset at the time, and Wedro was sympathetic to secession in 1955. Having invested their lives in the Party, they were unlikely to confront the fact that the union they built had been sacrificed to a merger of questionable worth. Taub later claimed in an oral history that the merger as a way to protect a "little union" within the "larger family of labour," but lamented the "undemocratic trampling" of workers rights with the removal of elected leaders — like himself — who were not even allowed to run again. ${ }^{12}$

The destructive impact of the Cold War stretched beyond specific union battles, and left an imprint on the broader labour movement, even after McCarthyism had waned. Two decades of Cold War rhetoric, in which communists and those who refused to denounce them were endlessly portrayed as a "fifth column of traitors" 113 had a dampening effect on left-wing dissent more generally. By labeling opponents traitors, spies, and saboteurs, trade union leaders were attempting to quell a fractious opposition, but this also became a much broader disciplining project that stifled rank and file dissent and genuine debate. In the current era, when Cold War-like fears are again prevalent, the need to make ample room for all forms of dissent, not giving in to a politics of fear, may be one lesson of the earlier Cold War in fur.

\section{NOTES}

1 On the history of the AMC, see David Brody, The Butcher Workmen: A Study in Unionization (Boston: Harvard University Press, 1964). 
Reginald Whitaker and Gary Marcuse, Cold War Canada: The Making of a National Insecurity State, $1945-57$ (Toronto: University of Toronto Press, 1994). They use the term insecurity state, developed by Wesley Wark, and note "an obses sive concern with security always presupposes an underlying degree of insecurity," xi.

3 Alvin Finkel, "Canadian Immigration Policy and the Cold War, 1945-80," Journal of Canadian Studies 21, no. 3 (Fall 1986): 77-107; Franca Iacovetta, "Freedom Lovers, Sex Deviates and Damaged Women: Iron Curtain Refugee Discourses in Cold War Canada," in Love, Hate, and Fear in Canada's Cold War, ed. Richard Cavell (Toronto: University of Toronto Press, 2004), 77-107.

4 Gary Kinsman, Dieter Buse and Mercedes Steedman, eds. Whose National Security? Canadian State Surveillance and the Creation of Enemies (Toronto: Between the Lines, 2000).

5 Reginald Whitaker and Steve Hewitt, Canada and the Cold War (Toronto: James Lorimer, 2003), 241.

6 Peter MacInnis, "Teamwork for Harmony: Labour-Management Production Committees and the Post-War Settlement in Canada," Canadian Historical Review 77 (Sept. 1996): 317-52.

7 In Canada, a few studies partisan to the CCF/social democrats suggest the purges were needed: Desmond Morton, Working People: An Illustrated History of the Canadian Labour Movement (Montreal: McGill Queens University Press, 1998); Terry Copp and Al Knipfel, The IUE in Canada: A History (Elora: Cumnock Press, 1980).

8 Irving Abella, Nationalism, Communism and Canadian Labour (Toronto: University of Toronto Press, 1973), 110. See also Jerry Lembeck and William Tattam, One Union in Wood: A Political History of the International Woodworkers of America (New York: International Publishers, 1984); Jim Green, Against the Tide: The Story of the Canadian Seaman's Union (Toronto: Progress Books, 1986); William Kaplan, Everything that Floats: Pat Sullivan, Hal Banks and the Seaman's Union of Canada (Toronto: University of Toronto Press, 1992). American works include Steve Meyer, Stalin over Wisconsin: The Making and Unmaking of Militant Unionism, 1900-50 (New Brunswick: Rutgers University Press, 1992); Roger Keeran, The Communist Party and the autoworkers' Unions (Bloomington: Indiana University Press, 1980); Martin Halpern, UAW Politics in the Cold War Era (Albany: SUNY Press, 1988); Bert Cochran, Labor and Communism: The Conflict that Shaped American Unions (Princeton: Princeton University Press, 1977); Harvey Levenstein, Communism, Anticommunism and the CIO (Westport: Greenwood Press, 1981); Steve Rosswurm, ed., The CIO's Left-led Unions (New Brunswick: Rutgers University Press, 1992); Robert Cherny, William Issel, and Kieran Taylor, eds., American Labor and the Cold War: Grassroots Politics and Post-War Political Culture (New Brunswick, NJ: Rutgers University Press, 2004). While the American literature is too vast to cite, one difference is their concern with issues of "race" and the Cold War's effect on the collapse of organizing in the South in the post war period: for example, Robert Kornstad, Civil Rights Unionism: Tobacco Workers and the Struggle for Democracy in the Mid-Twentieth Century South (Chapel Hill: University of North Carolina Press, 2002); Michael Honey, "Operation Dixie, the Red Scare and the Defeat of Southern Labor Organizing," in American Labor and the Cold War, 216-44. On the international scene see Denis McShane, International Labour and the Cold War (Oxford: Clarendon Press, 
1992).

9 Canadian examples include John Manley, "Starve, Be Damned: Communists and Canada's Urban Unemployed," Canadian Historical Review 79 (Sept 1998); Joan Sangster, Dreams of Equality: Women on the Canadian Left, 1920s-1950s (Toronto: Oxford University Press, 1989); Mercedes Steedman, "The Promise: Communist Organizing in the Needle Trades: The Toronto Dressmakers Campaign, 1928-7," Labour/ le Travail 34 (Autumn 1994): 37-74. US examples are Mark Naison, Communists in Harlem During the Depression (Urbana: University of Illinois Press, 1983); Robin Kelley, Hammer and Hoe: Alabama Communists During the Great Depression (Chapel Hill: University of North Carolina Press, 1990). This tradition is not confined to an earlier New Left. One example of a recent book which emphatically stresses the local is Randi Storch, Red Chicago: American Communism at its Grassroots, 1928-35 (Urbana: University of Illinois Press, 2007).

10 Nor is Stalinism simply defined as 'Moscow control.' Bryan Palmer, "Rethinking the Historiography of United States Communism," American Communist History 2, no. 2 (2003): 139-73.

11 Whitaker and Marcuse, Cold War Canada, 341.

12 Trades and Labour Congress Journal (TLCJ), Oct. 1950, 11; Jan 1951, 4; March 1951, 5.

13 "Soviet Communism is Anti-Christian," The Canadian Unionist (CU), April 1948, 75; A.D. Dunton, "Communists Openly Admit Disloyalty," CU, March 1949, 55; "Freedom for Whom?" CU, July-August 1954, 231.

14 John Boyko, Into the Hurricane: Attacking Socialism and the CCF (Winnipeg: J. Gordon Schillingford, 2006).

15 Whitaker and Hewitt, Canada and the Cold War, 43.

16 Jacques Rouillard, Histoire du Syndicalisme Québéçois (Montréal: Boréal, 1989), 2601; Mike Solski and John Smaller, Mine Mill: The History of the International Union of Mine, Mill and Smelter Workers in Canada since 1895 (Ottawa: Mutual Press, 1984); Kaplan, Everything That Floats.

17 Elaine Tyler May, Homeward Bound: American Families in the Cold War Era (New York: Basic Books, 1988); John D’Emilio, Sexual Politics, Sexual Communities: The Making of a Homosexual Minority in the US, 1940-70 (Chicago: University of Chicago Press, 1983).

18 Dorothy Sue Cobble, The Other Woman's Movement: Workplace Justice and Social Rights in Modern America (Princeton: Princeton University Press, 2004).

19 Lisa Kannenberg, “The Impact of the Cold War on Women's Trade Union Activism: The UE Experience," Labor History 34, no. 2 (1993): 309-23.

20 The International Fur Workers Union was founded in 1913 in the US. In 1938 it merged with the Leather Workers to become the International Fur and Leather Workers Union. It also moved to the CIO in 1938. The official history of the US leftled union is Philip Foner, The Fur and Leather Workers Union: A Story of Dramatic Struggles and Achievement (Newark: Nordan Press, 1950). On the Canadian fur industry, Ernest Strauss, “The Canadian Fur Manufacturing Industry” (MA thesis, McGill University, 1964).

21 Cornell University (CU), Kheel Centre for Labor-Management Documentation and Archives (Kheel), International Fur and Leather Workers Union Papers (IFLWU), Box 25, Folder 29, Winnipeg Fur Workers Local 91 Membership List.

22 For a more detailed analysis of these divisions see Ruth Frager, Sweatshop Strife: Class, 
Ethnicity and Gender in the Jewish Labour Movement, 1900-39 (Toronto: University of Toronto Press, 1992), 87-89.

23 Archives of Ontario (AO), Multicultural History Society of Ontario (MHSO), MU 9011, Interview with $\mathrm{Al}$ Hershkovitz.

24 This recruitment effort, supported by unions, businesses and the government sought primarily single men - in part due to a housing crisis and also a reflection of immigration policy which imagined women only as wives and maids. Of the 500, only sixty percent were supposed to be 'of the same religious group.' This quota, clearly antiSemitic, was imposed behind the scenes by the federal government. Library and Archives Canada (LAC), Dept. of Labour RG 27, Vol. 279, File 1-26-5-2, 'Fur Workers'; AO, Interview with Al Hershkovitz.

25 LAC, Joseph Cohen Papers, MG 30 A118 (hereafter Cohen Papers), Vol. 2, File 1145 , Letter from Minimum Wage Board, 19 May 1932 to Hallman and Sable Fur Company. Cohen (known for his communist sympathies) was acting for the company in this case.

26 AO, Abella Oral History Collection (AOHC), Muni Taub interview, nd. On the garment industry in the interwar period see Frager, Sweatshop Strife and Mercedes Steedman, Angels of the Workplace: Women and the Construction of Gender Relations in the Canadian Clothing Industry, 1890-1940 (Toronto: Oxford University Press, 1997).

27 LAC, Cohen Papers, Vol. 16, File 9.

28 For a similar situation in the garment industry see Gerald Tulchinsky, "Jewish Labour and Business in the Dressmakers Strikes of the 1930s: A Clash of Cultures in Confined Spaces," in, Espace et culture/Space and Culture, eds. S. Courville et Normand Seguin (St Foy: Presses de l’Université de Laval, 1995), 369-7.

29 CU, Kheel Centre, IFLWU, Box 25, Files 24, 25, 26, as well as Box 7, File 4. See also Toronto Star, 7 May 1937, and AO, AOHC, interview with Pearl Wedro, nd.

30 On Wedro and Coodin see Sangster, Dreams of Equality, 79, 131, 78 and Frager, Sweatshop Strife, 156-7. Militants in the labour movement have recently used Coodin's name as their anonymous nom de plum. See Freda Coodin, "The CAW turn bargaining versus building," Canadian Dimension (Nov-Dec. 2005), 36.

31 Ruth Frager argues that dual unions had negative consequences for fur workers in the 1930s, though Mercedes Steedman maintains that 'breakaway' communist unions in the garment trade had some positive implications for marginalized women workers: Frager, Sweatshop Strife, and Steedman, "The Promise: Communist Organizing in the Needle Trades."

32 Frager, Sweatshop Strife, 203.

33 LAC, United Food and Commercial Workers Papers (UFCW), MG 28 I 186, Acc. 1992/0101, Vol. 4, File 'testimonial dinner,' 5th Annual Jubilee Banquet of 1942 included a Federman-written history of the union, saying AFL locals in Seattle and Washington followed in Toronto's heroic example.

34 Gerry Tulchinksy, Branching Out: The Transformation of the Canadian Jewish Community (Toronto: Stoddart, 1998), 133. Harry Simon later became a staffer in the Ontario Federation of Labour (OFL) and was active in the CCF/NDP, running for office under their banner. AO, AOHC, Interview with Harry Simon, nd.

35 For example, in one court case the CIO group sued the AFL one for office property: see LAC, Cohen Papers, Vol. 11, File 2688. This designation of social democratic versus communist unions oversimplifies, as some fur workers obviously did not fit those 
categories, but it is a useful way of distinguishing the two main leadership groups.

Gerald Tulchinsky argues that the communist-influenced United Jewish Peoples Order supported immigration to Palestine after 1948, and was simply critical of the "excessively Zionist character of the Canadian Jewish Congress" in Branching Out, 130.

37 AO, Hershovitz interview.

38 LAC, Cohen Papers, Vol. 1, File International Fur and Leather Workers Union, court proceedings, 14 March, 1938, reprinted in Report of Executive, Toronto District Labour Council, Upon Investigation Conducted By It, re Furriers Toronto (hereafter TDLC Investigation), 1938.

39 AO, MHSO, Hershkovitz interview. For example, in the 1937 provincial election, communist J.B. Salsberg had been opposed by fur union leader and CCFer Harry Simon.

40 On Cohen, see Laurell Sefton MacDowell, Renegade Lawyer: The Life of J.L. Cohen (Toronto: University of Toronto Press, 2001).

41 LAC, UFCW, Acc. 1992/0101, Vol. 4, File 'correspondence,' pamphlet to 'all fur unionists in Toronto' and letter to Toronto District Labour Council, 26 March 1938.

42 On the full charges and investigation see AO, MHSO, MU 9021 Muni Taub papers, File 8428; interview with Al Hershkovitz; and LAC, Cohen papers, Vol. 1, File International Fur and Leather Workers Union. This investigation is mentioned in Frager, Sweatshop Strife, 203. The belief that Federman was guilty intensified communist antagonism to him in the 1940s, preventing an effort made in 1946 to effect a peace treaty between the two unions.

$43 \mathrm{AO}$, Taub interview.

44 Fears which were justified. See Alan Davies, ed., Antisemitism in Canada: History and Interpretation (Waterloo: Laurier University Press, 1992); Irving Abella and Harold Troper, None Is Too Many: Canada and the Jews of Europe, 1933-48 (Toronto: Lester and Orpen Dennys, 1982); Cyril Levitt and William Shaffir, "The Swastika as Dramatic Symbol: A Case Study of Ethnic Violence in Canada," in The Jews in Canada, eds. Robert Brym, William Shaffir and Morton Weinfeld (Toronto: Oxford University Press, 1993), 77-96.

45 AO, MHSO F 1405, Fur Workers, MS 1192, pamphlet, circa 1939.

46 Ibid.

47 AO, MHSO F 1405, Series 85, Fur Workers Union, File 8428, Maurice Wax to President of the Independent Fur Manufacturers Association, 27 May 1940; pamphlet of 24 April 1940.

48 CU, Kheel, IFLWU, Box 28, File 19, Ben Gold to Fred Collins, 30 Jan. 1945. Gold noted the exception to this rule: Joshua Gershman. On Gershman, see Irving Abella, "Portrait of a Jewish Professional Revolutionary: The Recollections of Joshua Gershman," Labour/Le Travail 2 (1977): 184-213.

49 University of British Columbia Special Collections (UBC), Trade Union Research Bureau Collection, Box 39, IFLWU, File 39-5.

50 CU, Kheel, IFLWU, Vol. 28, File 1, Haddow to Gold, 11 June 1954. Younger workers may have been drawn into anti-communist union efforts in part because they lacked the historic ties that older workers had to the union that initially organized them. See Gerald Zahavi, "Fighting Left-Wing Unionism: Views from the Opposition to the IFLWU in Fulton Co, NY," in The CIO's Left-Led Unions, 159-81. 
51 LAC, UFCW, Acc.1992/0101, Vol. 2, File 'Fur Workers Montreal.'

52 Cochran, Labor and Communism, 295.

53 CU, Kheel, ILFWU, Vol. 28, File 1, Gold to Haddow, 21 Jan. 1954.

54 A small trade union protest emerged around the Duplessis bill, but not because labour leaders had any desire to defend the civil rights of communists. In Quebec, the Catholic unions called for the 'outlawing' of communism. See CSN and CEA, The History of the Labour Movement in Quebec, trans. Arnold Bennett (Montreal: Black Rose Books, 1987), 166.

55 See CU, Kheel, IFLWU, Vol. 28, File 1, Haddow to Gold, 25 Jan. and 11 June 1954, and to Abe Feinglass, 28 Dec., 1954.

56 LAC, Communist Party of Canada Papers (CPC), MG 28 IV 4, Vol. 51, File International Fur and Leather Workers Union, Toronto Furrier, July 1955.

57 The post 1947 Cominform was made up of the more important European Communist Parties. Norman Penner, Canadian Communism: The Stalin Years and Beyond (Toronto: Methuen, 1988), 218.

58 State Historical Society of Wisconsin Archives (SHWA), Amalgamated Meat Cutters and Butcher Workmen Records (AMC), Box 5, Folder 205, Officers Report to the Special Convention IFLWU, 20-23 Jan. 1955.

59 One reference refers to the nine million dollar "treasury" involved in the deal, but another, which seems more realistic, refers to about $\$ 250000$ plus the White Lake Camp valued at 1.3 million. AFL Executive Council minutes, 1-10 February 1955 and 2-4 May 1955; SHSW, AMC, Reel 159, Earl Jimerson to Pat Gorman, 20 July 1955. If the 1.3 million is accurate, it is astounding the IFLWU (and by association, the Communist Party) were willing to sign away so much.

60 AFL-CIO Executive Minutes, "Confidential AMC Analysis of Proposed Merger Agreement," Dec. 1954.

61 WSHS, AMC Papers, Reel 160, Pat Gorman to Salvatore DiSano, President Local 328, 15 Feb. 1955. See also Reel 160, Pat Gorman to William Kelly, 6 Jan. 1955.

62 On HUAC [House on Un-American Activities Committee] see WSHS, AMC, Reel 159, Thomas Beale to Pat Gorman, 18 May 1955; Reel 158, Gorman to Donald Appell, 30 Aug. 1957.

63 AFL Executive Council Minutes, Dec. 1954, Letter from Vice-President Beck (Teamsters) to Meany, 7 Dec. 1954.

64 William Kashtan, “A New Era for Labour,” Canadian Tribune, 2 May 1955.

65 The fact that Feinglass had once taken the fifth before HUAC meant his loyalty was continually questioned, but the AMC believed in his "conversion."

66 AFL Executive Minutes, 2-4 May 1955. See also comment that Feinglass should be judged very "sincere" in his anti-communism since he went to Canada to "get rid of Haddow and Ferguson.” WSHS, AMC, Reel 159, Earl Jimerson to Pat Gorman, 20 July 1955.

67 AFL Executive Council Minutes, 2-3 May 1955.

68 WSHS, AMC, Reel 159, Simon list. This is found, both in typed and handwritten entries, in many places in AMC papers, as a tally was kept of those "eliminated" (the language usually used).

69 WSHS, AMC Papers, Reel 160, Claude Jodoin to Pat Gorman, 11 Jan. 1955.

70 LAC, Haddow Papers, Vol. 1, IFWLU file, transcript of March 1955 convention. 
71 Ibid.

72 They had earlier reassured Simon with this statement. WSHS, AMC, Reel 160, Pat Gorman to Harry Simon, 29 Dec. 1954.

73 WSHS, AMC, Reel 159, Pat Gorman to Rev Charles Rice, 23 Feb 1955. A Roman Catholic priest based in Pittsburgh, Charles Owen Rice was a major anti-communist crusader in the US. See John Hoerr, Harry, Tom, and Father Rice: Accusation and Betrayal in America's Cold War (Pittsburgh: University of Pittsburgh Press, 2005).

74 For example in April Gorman told the AFL that "ten" in Canada had been eliminated from having any connections to the AMC, though they had not all resigned yet. Reel 160, Pat Gorman to George Meany, 25 April, 1955.

75 LAC, Haddow Papers, Vol. 1, IFLWU file, 19 May District Board meeting; "Fur Union leader's resignation accepted under protest," Canadian Tribune, 30 May 1955.

76 AFL Executive Council Minutes, 2-4 May 1955.

77 WSHS, AMC, Reel 158, Statement of Vancouver Joint Board, 4 June 1955.

78 LAC, CPC Papers, Vol. 51, IFLWU District Meeting, July 26, 1955.

79 CA, Kheel, IFLWU, Vol. 28, File 1, Haddow to Feinglass, 5 Oct. 1954 and 11 June, 1954.

80 LAC, Haddow Papers, Vol. 1, IFLWU file, Officers report to August meeting.

81 LAC, Haddow Papers, Vol. 1, IFLWU file, handwritten notes with two columns: 1. independence or 2. Federman: the independence column also had negatives, including the "suffering of workers in the trade," and "need for unity." In anonymous US correspondence, one writer also claimed that there was a "rackets" group within the AMC. WSHS, AMC, Reel 159, anonymous "My Analysis of the Situation."

$82 \mathrm{Al}$ Hershovitz remembers going, behind-the-scene, to persuade Communist Party leader Dave Kashtan that a breakaway union would be suicidal, but given the current line, Kashtan probably needed little convincing.

83 AO, MHSO, Al Hershokovitz interview.

84 Brody, The Butcher Workmen, 259-67; Levenstein, Communism, Anticommunism, 67.

85 Cochran, Labor and Communism.

86 Rejecting mainstreaming in the US, UE leader James Matles commented, "the mainstream is a sewer." Quoted in Doug Smith, Cold Warrior: C.S. Jackson and the United Electrical Workers (St John's: Canadian Committee on Labour History, 1997), 221.

87 WSHS, AMC, Reel 160, Pat Gorman to George Meany, 24 Jan. 1957. We are "watching Toronto" to make sure communists on the "list" do not run.

88 There are a series of letters between Mitchell and Gorman, with the latter relaying Meany's demands. WSHS, AMC, Reel 158, 7,12 June and 2, 19, 24 Oct. 1957.

89 LAC, United Food and Commercial Workers Papers (UFCW), Acc. 1992/0101, Vol 2, The Anti-Communist Fur Workers Voice, April 1957.

i90 WSHS, AMC, Reel 159, Pat Gorman to Father Charles Rice, 11 Feb 1955.

91 LAC, UFCW, Acc. 1992/0101, Vol. 4, Federman file.

92 He used the fur union to endorse the political "educational" role of the Jewish Labour Committee, both its fight against discrimination in Canada, and its later support abroad of the state of Israel. LAC, UFCW, Acc 1992/0101, Vol. 4, Federman file.

93 LAC, UFCW, Acc. 1992/0101, Vol. 4, 1970s file.

94 LAC, UFCW, Acc. 1992/0101, Vol. 4, Federman file.

95 "Ten Month Struggle Wins Pact at Humberstone Shoe," The Fur and Leather Worker 
(FW), March-April 1952; "Richmond Shoe Strike in 14th Week," and "Montreal Local 500 Shop Wins 5 cents Raise," FW, May 1950.

96 "New Officers Installed by Sister Wedro," FW, June 1949.

$97 \mathrm{AO}, \mathrm{AOHC}$, Wedro Interview.

98 My reading of gender politics is taken not only from Canadian sources, but also American ones: the IFLWU papers, convention reports, and a reading of their paper, The Fur and Leather Worker, though it contained a small amount of Canadian news.

99 CU, Kheel Library, IFLWU, 1946 Convention Minutes, 217.

100 CU, Kheel Library, IFLWU, 1950 Convention Minutes, 268.

101 Ibid., 1944 Convention Minutes, 209.

102 LAC, RCMP Papers, RG 18, Vol. 3526, Pamphlets, The Toronto Furriers Newsletter, June, 1954.

103 CA, Kheel Library, IFLWU Papers, Vol. 25, Folder The Beaver (newsletter of the Toronto union)

104 “Women's Parley Maps New Activities," FW, April-May 1951.

105 CA, Kheel Library, IFLWU Convention Report, 1946, 219.

106 AO, MHSO, Interview with Hershvovitz.

107 Whitaker and Marcuse, Canada's Cold War, chap. 14. This deals primarily with the Canadian Seaman's Union case.

108 Jerry Lembecke, "Class Capacities and Labor Internationalism: The Case of the CIOCCL Unions,” Critical Sociology 15, no. 4 (1988): 80-93.

109 For both quotes, LAC, UFCW, Acc.1992/0101, Vol. 4, Federman file, 1972 Address to Convention and 1942 Annual Jubilee Banquet. In the former case, he also suggested that they they were involved in the shooting of Walter Reuther.

110 LAC, UFCW, Acc. 1992/0101, Vol. 4, File Testimonial dinner, 1947.

111 His history is "shallow and inadequate" and if anyone should write the history, it should be you, Gorman told Feinglass, WSHS, AMC, Reel 154, Federman file, Gorman to Feinglass 24 Feb and 4 March 1960.

112 AO, MHSO, AOHC, Interview with Muni Taub.

113 AO, MHSO, F 1405, MU 9201, Waxman to Fur Manufacturers Association, 27 May and 24 April, 1940. 